\title{
T-cell response to $\mathrm{p53}$ tumor-associated antigen in patients with colorectal carcinoma
}

\author{
MARCO BUETER $^{1}$, MARTIN GASSER ${ }^{1}$, NICOLAI SCHRAMM ${ }^{2}$, TATIANA LEBEDEVA ${ }^{3}$, GEORGES TOCCO $^{4}$, \\ CHRISTIANE GERSTLAUER ${ }^{2}$, MARTIN GRIMM ${ }^{2}$, EKATERINA NICHIPORUK ${ }^{2}$, ANDREAS THALHEIMER ${ }^{1}$, \\ ARNULF THIEDE $^{1}$, DETLEF MEYER ${ }^{1}$, GILLES BENICHOU ${ }^{4}$ and ANA MARIA WAAGA-GASSER ${ }^{2}$ \\ Departments of ${ }^{1}$ Surgery I and ${ }^{2}$ Molecular Oncology and Immunology, University of Wuerzburg, \\ D-97080 Wuerzburg, Germany; ${ }^{3}$ American Red Cross, New England Region, Dedham, MA 02026; \\ ${ }^{4}$ CMI Laboratory, Massachusetts General Hospital, Department of Surgery, Transplantation Unit, \\ Harvard Medical School, Boston, MA 02114, USA
}

Received August 17, 2005; Accepted October 14, 2005

\begin{abstract}
Despite the radical surgical resection performed in patients with colorectal carcinoma, there is a high rate of tumor recurrence. Over an observation period of 3 years, 18\% of the patients in our collective suffered a tumor relapse with local or distinct metastases after initial R0-resection. Some evidence suggests that this may be due to suppression of antitumor responses, a phenomenon that might be attributed to regulatory $\mathrm{T}$ cells. The aim of our study was to investigate the tumor-specific immune response depending on the UICC stage of patients with colorectal cancer. The cellular immune responses against defined antigens that are overexpressed in most of the patients with colorectal cancer were characterized. For this purpose, the tumor suppressor gene, p53, was chosen as the tumor-associated antigen that exhibits mutations and overexpression in up to $60 \%$ of colorectal carcinoma. We observed that p53 induced both IFN- $\gamma$ and IL-10 secretion. The predominance of IL-10 production indicated that regulatory $\mathrm{T}$ cells directly participate in modulating the anti-tumor immune response. IL-10 levels in the blood as well as the expression of regulatory $\mathrm{T}$-cell specific genes at the tumor site correlate with the UICC stage of the disease. These results may provide an explanation for the poor prognosis and increased recurrence rate in patients with advanced carcinoma.
\end{abstract}

Correspondence to: Professor Ana Maria Waaga-Gasser, Department of Surgery I, Molecular Oncology and Immunology, University of Wuerzburg, Zentrum Operative Medizin (ZOM), Oberduerrbacher Str. 6, D-97080 Wuerzburg, Germany

E-mail: waaga-gasser@chirurgie.uni-wuerzburg.de

Abbreviations: TAA, tumor-associated antigen; MHC, major histocompatibility complex; DC, dendritic cell; CTL, cytotoxic T lymphocytes; PBLs, peripheral blood lymphocytes; UICC, International Union Against Cancer

Key words: p53, immune response, $\mathrm{T}$ cells, cancer, tumor antigens

\section{Introduction}

Mutations in the p53 gene are the most frequently reported somatic gene alterations in human malignancies. This results in an overexpression and cytosolic accumulation of the p53 protein, a phenomenon observed in more than half of all cancers. This ubiquitous expression of mutated p53 in tumors has prompted immunologists to use p53 as an antigen for the design of immunological therapies in cancer $(1,2)$. The possibility of using wild-type (wt) p53 as an effective tool for immune intervention has been demonstrated in several mouse tumor models. Studies in rodents have demonstrated the immunogenicity of p53 during tumorigenesis and the induction of $\mathrm{CD}^{+}$and $\mathrm{CD}^{+} \mathrm{T}$-cell responses directed to $\mathrm{p} 53$ determinants. While T-cell responses to p53 are consistently induced during cancer, they fail to eradicate tumors. It is noteworthy, however, that p53 immunization can lead to the differentiation of p53-specific $\mathrm{CD}^{+} \mathrm{T}$ helper and $\mathrm{CD} 8^{+}$cytotoxic $\mathrm{T}$ cells capable of rejecting tumors in mice $(3,4)$. This supports the view that, in the absence of vaccination, anti-p53 T cells capable of rejecting tumors are either never activated or that they are suppressed by other T cells. In support of this view, our laboratory has previously reported that the vast majority of p53-specific CD4 ${ }^{+} \mathrm{T}$ cells expanding in mice with $\mathrm{J} 774$ sarcomas secrete type 2 cytokines (IL-4, IL-5, IL-10). This observation suggests that in tumor-bearing mice, while p53 is immunogenic it preferentially activates $\operatorname{Th} 2 / \operatorname{Treg}(\operatorname{Tr} 1)$ cells, a response which does not lead to tumor rejection or even protects tumors from eradication by Th1 cells. It is still not clear whether polarization of anti-p53 response to Th2/Treg immunity during tumorigenesis represents a general phenomenon that is relevant to patients with different cancers. As we gain insights into these questions, we may design new methods of therapeutic intervention to manoeuvre the anti-p53 T-cell response towards effective tumor rejection.

Mutations within the p53 gene have been demonstrated in a large proportion of colorectal cancer patients (5). Although MHC class II molecules are usually not expressed on the surface of solid tumors, which makes direct tumor eradication by $\mathrm{CD}^{+}{ }^{+} \mathrm{T}$ helper cells impossible, there is cumulative evidence 
of their crucial role in anti-tumor immunity (6). In addition, the recognition by $\mathrm{T}$ helper cells of tumor antigens processed and presented by professional antigen presenting cells (APCs), such as dendritic cells (DC), can lead to a variety of events. These events include the activation of anti-tumor specific cytotoxic T lymphocytes (CTL), the production of antibodies by $\mathrm{B}$ lymphocytes, and the mobilization of innate effector mechanisms including the activation of tumoricidal macrophages, eosinophils and NK cells (7-10). These results demonstrate that $\mathrm{p} 53$-specific $\mathrm{T}$ helper cells (Th) can provide help to p53-specific CTL, thereby controlling tumor growth $(11,12)$. Obviously, the p53-specific Th responses detected in patients with primary colorectal cancer fail to ensure tumor eradication, rendering necessary surgical removal of life-threatening tumors. Some so called 'escape mechanisms' may account for the lack of tumor eradication by the immune system. They include the loss or downregulation of MHC class I molecules on the tumor surface with a lack of sufficient CTL immunity (13-15), the loss of tumor antigens $(16,17)$, and the lack of co-stimulation followed by T-cell anergy rather than activation $(18,19)$. It is possible that all these events are driven by the production of regulatory cytokines by the tumor by Th2/Treg cells $(20,21)$, but this hypothesis remains to be investigated.

In this study, we evaluated p53-specific $\mathrm{T}$ helper immunity in 51 patients with primary colorectal cancer at various UICC stages of disease. We measured p53-specific production to type $1(\mathrm{IFN}-\gamma)$ and type 2 (IL-10) cytokine by T cells, the expression levels of p53 in the tumor, the humoral anti-p53 response, and the infiltration of tumor by Th2 cells, which have been associated with a higher level of tumor recurrence and a reduction in disease-free survival (22). We showed that p53 induced both IFN- $\gamma$ and IL-10 secretion. The predominance of IL-10 production indicated that regulatory $\mathrm{T}$ cells directly participate in modulating the anti-tumor immune response. IL-10 levels in the blood as well as the expression of regulatory T-cell specific genes at the tumor site correlate with the UICC stage of the disease.

\section{Patients and methods}

Patients. Fifty-one patients diagnosed with primary colorectal cancer were included in this study. The protocol used was approved by the local medical ethics committee. Heparinized peripheral blood and tumor tissue were collected from patients with informed consent before surgery. Blood samples were separated on Lymphoprep according to the manufacturer's instructions (Nycomed Pharma, Oslo, Norway). Peripheral blood lymphocytes (PBLs), sera, and tumor specimens were either promptly used or stored at $-80^{\circ} \mathrm{C}$. Tumors were evaluated for location, stage, and differentiation grade. Data concerning age, gender, level of wall infiltration, and lymph node metastasis were collected in our database.

Peptides. Ninety-four peptides spanning the whole length of wt $\mathrm{p} 53$ protein were synthesized on either polyethylene pins or polystyrene resin following the standard conditions for activation, Fmoc deprotection, and side chain deprotection and cleavage for custom peptides (Mimotopes, Clayton Victoria, Australia). p53 peptides were synthesized as 14-mers over- lapping by 4 amino acids and divided into 10 pools: pool 1 (residues 1-50), pool 2 (residues 51-90), pool 3 (residues 91-130), etc.

Humoral response to p53. p53-specific IgG titers were quantified using the commercially available p53 ELISA Kit (Oncogene, Boston, MA, USA). The results for each serum sample were calculated first by determining the relative p53 autoimmune index, following the manufacturer's calculation protocol (cut off value: 0.035$)$. The anti-p53 IgG titer $(\mathrm{U} / \mathrm{ml})$ of the positive serum samples was calculated at 50x dilution using the linear regression curve obtained by plotting the concentration of standards versus the absorbance. In all the ELISA experiments, patient sera were tested in duplicate and the experiments repeated 3 times. Sera from healthy patients were used as controls.

IFN- $\gamma$ enzyme-linked immunosorbent assay (ELISA). Supernatants from ELISPOT assay (described below) were collected and measured for IFN- $\gamma$ production by ELISA using BioSource Cytoscreen kits (BioSource, Camarillo, CA), following the manufacturer's protocol.

ELISPOT assay. The ELISPOT assay used to measure the frequency of p53 reactive $\mathrm{T}$ cells producing IL-10 was performed as previously described. Briefly, ELISPOT plates (Millipore, Molsheim, Germany) coated with capture antibody against IL-10 (BD Bioscience, Heidelberg, Germany) in phosphate-buffered saline (PBS) were left overnight at $4^{\circ} \mathrm{C}$. The plates were blocked with $1 \%$ BSA in PBS for $2 \mathrm{~h}$ and then washed with PBS. PBLs $\left(1 \times 10^{5}\right)$ in $100 \mu 1$ of complete RPMI medium (RPMI-1640 medium (Invitrogen, Karlsruhe, Germany) with $10 \%$ normal human serum (PAA, Coelbe, Germany), $100 \mathrm{U} / \mathrm{ml}$ penicillin (Biochrom, Berlin, Germany), $100 \mu \mathrm{g} / \mathrm{ml}$ streptomycin (Biochrom), $5 \mathrm{mM}$ HEPES (Biochrom), $1 \%$ non-essential amino acids (Biochrom) $1 \mathrm{mM}$ sodium pyruvate (Biochrom), and $2 \times 10^{-5} \mathrm{M} 2$-mercaptoethanol (Invitrogen) was added to each well with the addition of the relevant p53 peptide pool ( $50 \mu \mathrm{g} / \mathrm{ml}$ of each peptide). Control wells contained cells plus either medium alone or PHA (final concentration, $5 \mu \mathrm{g} / \mathrm{ml}$ ) without the peptide. After $24 \mathrm{~h}$, the plates were washed and a biotinylated detection antibody (BD Bioscience) was added for $2 \mathrm{~h}$ at room temperature. After further washing, horseradish peroxidase (HRP) conjugate (BD Bioscience) was added for $1 \mathrm{~h}$ at room temperature in darkness. The development was performed with freshly prepared aminoethyl carbazole (AEC) (Pierre pharmaceuticals, Rockland, IL; $10 \mathrm{mg} / \mathrm{ml}$ in N, N-dimethylformamide) in $0.1 \mathrm{M}$ sodium acetate buffer ( $\mathrm{pH} 5.0)$ mixed with $30 \% \mathrm{H}_{2} \mathrm{O}_{2}(200 \mu \mathrm{l} /$ well). The resulting spots were counted on a computerassisted ELISA Spot Image Analyzer (CTL, Cleveland, OH). All experiments were repeated four times and the results are expressed as the frequency of cytokine-producing cells per million cells.

Immunohistochemistry. Representative biopsies of tumor samples were fixed in $10 \%$ buffered formalin for histological examination and PCR-analysis. Paraffin sections were evaluated using hematoxylin and eosin, and periodic acid Schiff (PAS). Additional biopsies were snap-frozen and stored at 
$-80^{\circ} \mathrm{C}$ for RNA extraction and RT-PCR analysis. Cryostat sections fixed in paraformaldehyde-lysine-periodate were prepared for cell-surface antigen staining. Monoclonal antibody (mAb), DO-7 (anti p53, 35-45), from DakoCytomation (Heidelberg, Germany); anti-CD4-mAb, anti-CD25-mAb, control mAbs and secondary antibodies from BD Pharmingen (Heidelberg); and Isotype-matched mAbs or purified IgG1 and controls for residual endogenous peroxidase activity were included in each experiment. The percentage of tumor cell staining for p53 and the intensity of staining of the nucleus (low, medium, or high) was estimated within 20 consecutive high-power fields (magnification $\mathrm{x} 40$ ).

RNA extraction. RNA was extracted using an RNA extraction kit (Qiagen, Hilden, Germany) from at least $10 \mathrm{mg}$ of homogenized tumor tissue, washed in DEPC-75\% ethanol before being dissolved in DEPC-water, and stored at $-70^{\circ} \mathrm{C}$ until further analyses. The amount of total RNA was determined by measuring absorbance at $260 \mathrm{~nm}$. The purity of the total RNA was established by confirming that the $260 \mathrm{~nm}: 280 \mathrm{~nm}$ ratio was within a 1.8-2.0 range, indicating that the RNA preparations were free of protein contaminants.

Reserve transcriptase polymerase chain reaction ( $R T-P C R)$ for detection of p53 mutations. cDNA was prepared from $2 \mu \mathrm{g}$ of total RNA using the Promega AccessQuick ${ }^{\mathrm{TM}}$ RT-PCR System (Promega, WI, USA). The procedure was performed according to the standard RT-PCR protocol using AMVreverse transcriptase. Two sets of primers amplifying the p53 coding region spanning exons 4 and 9 were used. The primer sequences were as follows: for exons 4-6, sense primer TGT CCC CGG ACG ATA TTG AAC and antisense primer TTC CTT CCA CTC GGA TAA GAT GC (amplicon size 465 bp); and for exons 5-9, sense primer GCT CAG ATA GCG ATG GTC TGG C and antisense primer TCT CGG AAC ATC TCG AAG CG (amplicon size 484 bp). RT-PCR conditions for the first reaction were $48^{\circ} \mathrm{C}$ for $45 \mathrm{~min}$, followed by $2 \mathrm{~min}$ at $95^{\circ} \mathrm{C}$, followed by 40 cycles of $94^{\circ} \mathrm{C}$ for $30 \mathrm{sec}, 60^{\circ} \mathrm{C}$ for $60 \mathrm{sec}$, and $68^{\circ} \mathrm{C}$ for $20 \mathrm{sec}$; followed by $68^{\circ} \mathrm{C}$ for $5 \mathrm{~min}$. Before sequencing, all PCR products were purified following the QIAquick PCR purification kit protocol (Qiagen) using vacuum manifold. PCR products were blindly sequenced on an ABI PRISM 373 fluorescent dye terminator (PE/Applied Biosystems, Foster city, CA, USA).

Real-time polymerase chain reaction (real-time PCR) for Th2 specific genes in tumor specimens. mRNA expression of representative surface molecules and cytokines (CD4, CD25, Foxp3, GATA-3, CTLA-4, GITR, IL-10, IFN- $\gamma$ ) was analyzed in colorectal tumor specimens by real-time PCR $(n=21)$. RNA was extracted as described above. cDNA was prepared using $2 \mu \mathrm{g}$ of heat-denatured RNA. The following primer sequences were used (Sigma Genosys, Woodlands, TX): for GAPDH, 5'-ATC CCA TCA CCA TCT TCC AGG-3' and 5'-CGC CCC ACT TGA TTT TGG-3'; for CD4, 5'-TCC GTG TCT CAG CTG GAG C-3' and 5'-GAC AGT GCA TGT CCA GGT GC-3'; for CD25, 5'-AAG TCC AAT GCA GCC AGT GG-3' and 5'-TCC CTG CAG TGA CCT GGA AG-3'; for Foxp3, 5'-GAGAAGCTGAGTGCCATGCA-3' and 5'-GGT CAG TGC CAT TTT CCC AG-3'; for GATA-3,
5'-ACT ACC TGT GCA ACG CCT GC-3' and 5'-GGT TCT GTC CGT TCA TTT TGT GA-3'; for CTLA4, 5'-ATC GCC AGC TTT GTG TGT GA-3' and 5'-GAC CTC AGT GGC TTT GCC TG-3'; for GITR, 5'-CGA GGA GTG CTG TTC CGA G-3' and 5'-TGG AAT TCA GGC TGG ACA CAC-3'; for IL-10, 5'-CTA CGG CGC TGT CAT CGA TT-3' and 5'-CAC GGC CTT GCT CTT GTT TT-3'; and for IFN- $\gamma, 5$ 'TGT TGA ACT GCA CTG GCC A-3' and 5'-CAC CCA GGG CAG CTG GT-3'. Primers were designed using the Primer Express software for primer design to amplify short segments of 50-150 base pairs of target cDNA. Optimum primer concentration was determined by titration. Real-time quantitative PCR was performed in a two-step RT-PCR using SYBR-Green PCR Master Mix (PE Biosystems, Foster City, CA) with $100 \mathrm{ng}$ cDNA and $300 \mathrm{nM}$ of primers in a total reaction volume of $50 \mu \mathrm{l}$. PCR thermal cycling conditions were as follows: $95^{\circ} \mathrm{C}$ for $10 \mathrm{~min}$, followed by 40 cycles of $95^{\circ} \mathrm{C}$ for $15 \mathrm{sec}$ and $60^{\circ} \mathrm{C}$ for $60 \mathrm{sec}$. Gene specific products were continuously measured by an ABI PRISM 7700 sequence detector (Applied Biosystems, Foster City, CA) and relative quantification was performed following the manufacturer's instructions. All samples were assayed in duplicate and normalized during data analysis by a passive reference dye provided in the SYBR-Green PCR Master Mix to compensate for well-to-well fluorescence variations. The average threshold cycle $(\mathrm{Ct})$ value was calculated as the cycle number at which the fluorescence of the reporter reaches a fixed threshold. The difference $(\Delta \mathrm{Ct})$ between the average $\mathrm{Ct}$ values of the samples in the target wells and those of the housekeeping gene, GAPDH, was assessed, followed by the calculation of the difference between the average $\Delta \mathrm{Ct}$ values of the samples for each target and the $\Delta \mathrm{Ct}$ value of the control sample for that target $(\Delta \Delta \mathrm{Ct})$. The relative quantification value, fold change, is expressed as $2-\Delta \Delta \mathrm{Ct}$.

Statistical analysis. To compare the significance in differences in non-related data, the Mann-Whitney U test was performed. Significance was assumed if $\mathrm{p}<0.05$.

\section{Results}

Humoral response to $p 53$. We studied the relationship between the p53-specific antibody response and the expression of $\mathrm{p} 53$ in the tumor. The results were correlated with the stages of disease (UICC stage I-IV). All 51 patients, including the 20 for which PBLs were collected, were tested for the presence of p53-specific IgG serum antibodies and 39.2\% of the patients displayed p53-specific IgG serum antibodies $(n=20)$. Antibodies were not detectable or were below the critical range in 31 patients, these results were not taken into consideration. $25 \%$ of the patients with a positive antibody status were UICC stage I, 20\% were UICC II, 20\% were UICC III, and $35 \%$ were UICC IV. The majority of all tested patients (74\%) showed a negative serum response to $\mathrm{p} 53 \mathrm{IgG}$. No correlation was found between the levels of free p53 protein and the antibody levels of the patients (data not shown). Immunohistochemical analysis of p53 expression in the tumors showed that tumors of higher stages had a significantly stronger staining intensity than tumors of lower UICC stages (UICC III and IV $57.1 \%$ vs. I and II $37.1 \%$ positive cells expressing 


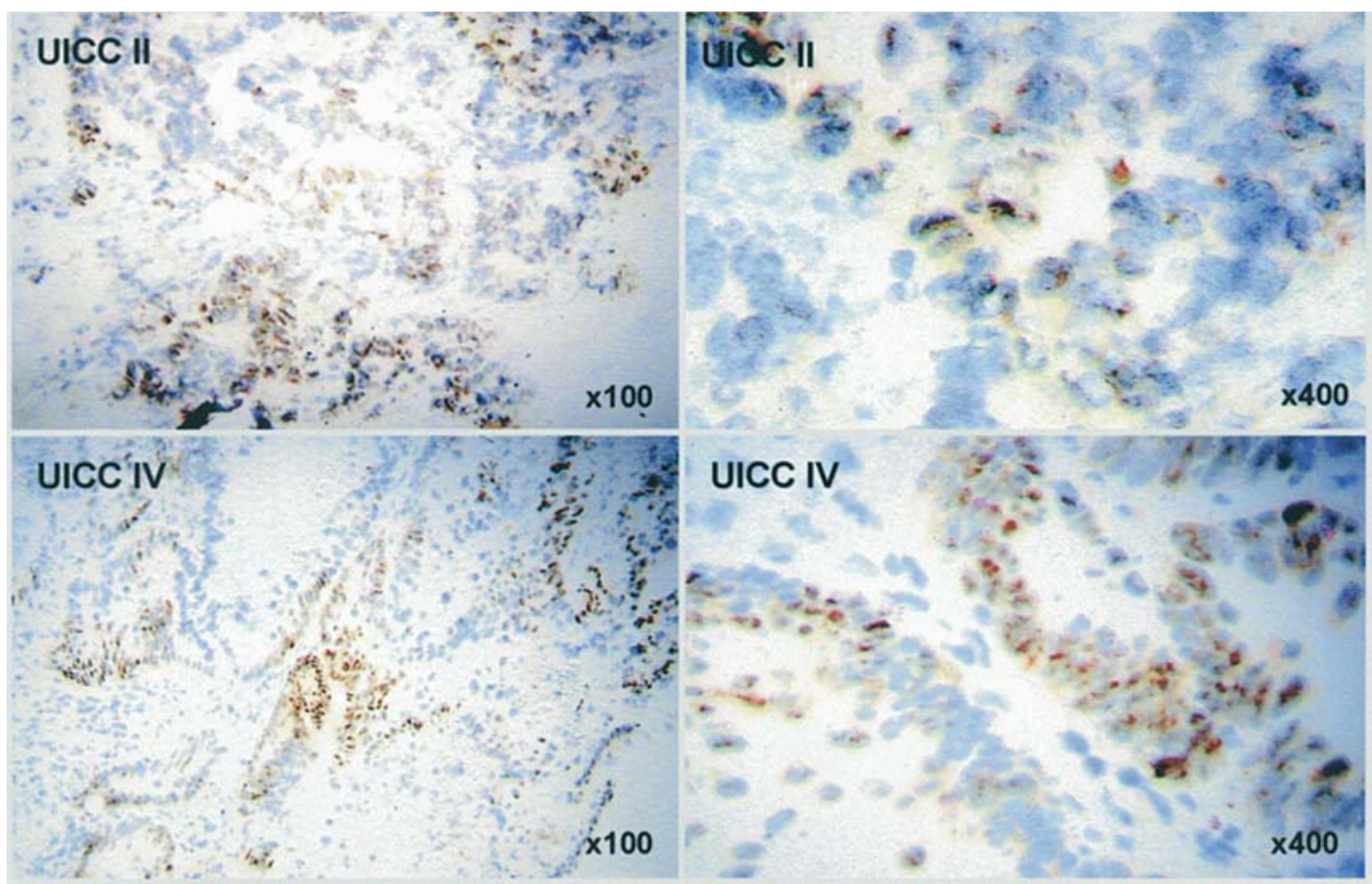

Figure 1. Immunohistochemical analysis of two representative tumor specimens (UICC stages II and IV) with strong intracellular p53 staining. Tumors of higher stages (UICC IV) showed a stronger staining intensity than those of lower UICC stages. The percentage of nuclear p53 staining intensity (low, medium, and high) in tumor cells was estimated within 20 consecutive high-power fields. Original magnifications, x100 and x400.

p53, p<0.05) (Fig. 1). The presence of p53-specific IgG antibodies correlated with a strong p53 staining intensity $(\mathrm{p}<0,05)$, suggesting a correlation between the intracellular accumulation of p53 in the tumor cells and the humoral response to p53 in accordance with previous studies $(23,24)$. In contrast, both the presence of a humoral response and UICC stage of disease showed no correlation with levels of free $\mathrm{p} 53$ protein in the sera.

p53-specific Thelper cell reactivity. Tumor-specific immune responses in patients with colorectal cancer in different UICC stages of disease were analyzed and their wild-type p53-specific regulatory T-cell function was characterized. After stimulation with the p53 peptide pools, two peptide pools (AA 1-50 and AA 291-330) were found to induce IL-10 production. We observed that the UICC stage was important in IL-10 production in response to the $\mathrm{p} 53$ peptide, AA 1-50. More Th2 cells producing higher IL-10 levels in response to the wild-type p53 peptide sequence, AA 1-50, were seen in patients with UICC stages I and II $(n=9)$ than in those with stages III $(\mathrm{n}=8)$ and IV $(\mathrm{n}=8)$ (mean value, I/II: $135 \pm 16$ spots/ $10^{5}$ cells, vs. III: $118 \pm 20$ spots $/ 10^{5}$, and IV: $90 \pm 17$ spots $/ 10^{5}$ cells, $\mathrm{p}<0.05)$. A decreased IL-10 expression was observed in the presence of the peptide pool, AA 291-330, in PBLs from patients in UICC stage III (mean value, I/II: $58 \pm 17$ spots $/ 10^{5}$ cells, vs. III: $26 \pm 12$ spots $/ 10^{5}$ cells, vs. IV: $62 \pm 13$ spots $/ 10^{5}$ cells, p<0.05) (Fig. 2). In contrast, p53 peptide sequence AA331-370 caused IFN- $\gamma$ production and no correlation was found between the UICC stage and the intensity of the Th1 immune response (Fig. 3). The presence of T helper immunity is not necessarily linked with a p53-specific IgG response. Pools of ten peptides were used in this study. More determinants inducing a Th2 type immune response than Th1 type were observed along the whole p53 protein sequence: AA 1-50 and AA 291-330 inducing IL-10 production vs. AA 331-370 inducing IFN- $\gamma$ production, indicating that the specific immune responses to 553 depend on the presented p53 protein determinant.

p53-specific humoral and cellular immunity in relation to p53 mutational status. p53 mutational status was analyzed in 16 of these patients with colorectal carcinoma. Five different point mutations located at 5 different sites along the p53 sequence were identified in their solid tumor biopsies [base pair (bp) 82 C:G, bp 300 T:C, bp 366 A:G, bp 686 T:C, bp $711 \mathrm{~T}: \mathrm{C}]$. p53 mutations showed no significant correlation with either the presence of p53-specific antibodies or elevated T-cell reactivity (data not shown). This observation is in concordance with previous studies demonstrating wild-type $\mathrm{p} 53$-specific $\mathrm{T}$ helper cell responses in patients with colorectal cancer, indicating that neither the presence of p53-specific antibodies nor the $\mathrm{T}$ helper immune response is necessarily linked to mutations in the p53 gene (25).

Characterization of tumor infiltrating lymphocytes by analysis of Th2 specific gene expression. Real-time PCR analysis revealed an increased expression of $\mathrm{T}$ regulatory specific genes (CD4, CD25, CTLA4, Foxp3, GATA-3, GITR, IL-10) at the tumor site in patients with UICC stage II (CD4, 13.3 $\pm 5 \Delta \mathrm{Ct}$; CD25, 11 $\pm 3.3 \Delta \mathrm{Ct}$; CTLA4, 20 $\pm 7.1 \Delta \mathrm{Ct}$; FOXp3, 23.8 $\pm 9.3 \Delta \mathrm{Ct}$; GATA-3, 21.8 $\pm 7.1 \Delta \mathrm{Ct}$; GITR, $20.4 \pm 6.4 \Delta \mathrm{Ct}$; IL-10, 10.1 $\pm 4.9 \Delta \mathrm{Ct}$ ). This indicates that, at this stage of disease, the population of regulatory tumorspecific $\mathrm{T}$ cells indeed comprises of $\mathrm{CD} 4{ }^{+} \mathrm{CD} 25^{+}$cells (Fig. 4). 
$\mathbf{A}$

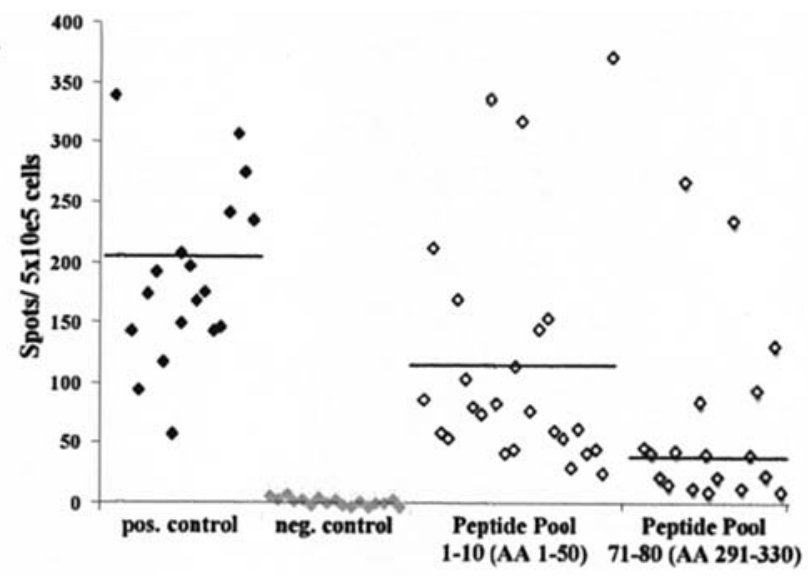

C

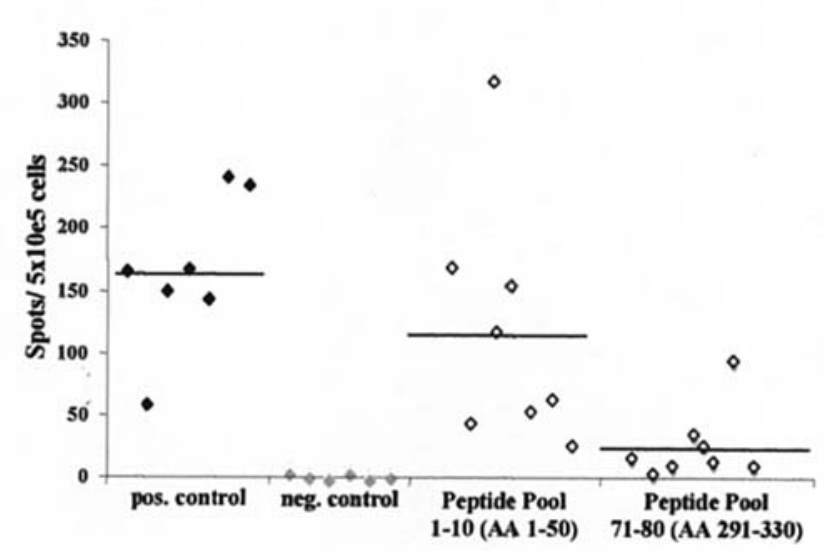

B

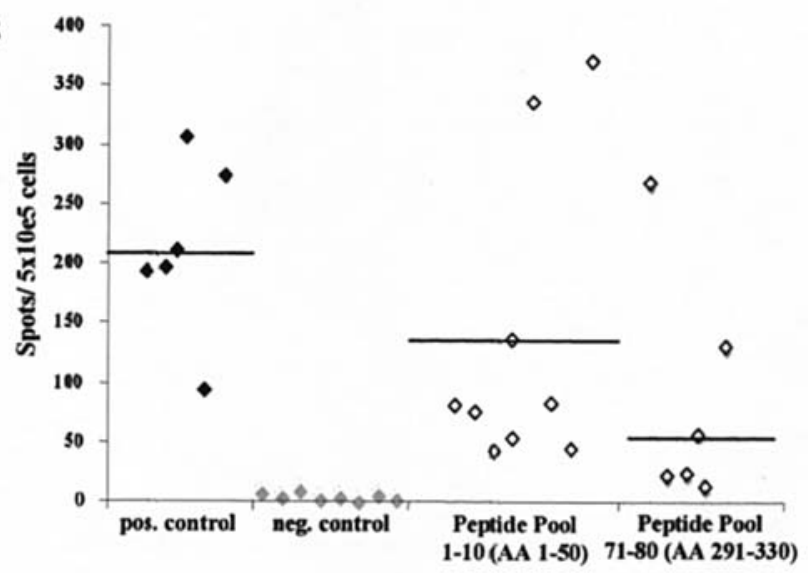

D

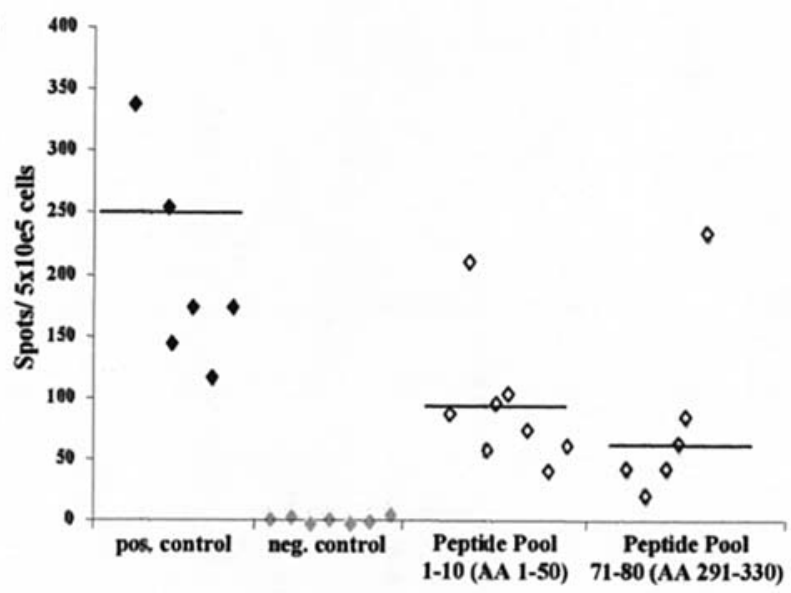

Figure 2. Expression of IL-10 in PBLs derived from patients (A) after stimulation with wild-type p53 peptides (AA1-50 and AA291-330) at UICC stages I/II (B), III (C), and IV (D). IL-10 production upon stimulation with these peptide pools was UICC stage dependent. Patients of UICC stage I/II showed more Th2 specific lymphocytes producing higher IL-10 levels in response to the peptide sequence, AA 1-50, than those of stages III and IV. A decreased IL-10 expression was observed in the presence of the peptide pool, AA 291-330, in patients of UICC stage III. Each dot represents one patient, the horizontal lines mark the mean value of the measured IL-10 expression (spots $/ 5 \times 10^{5}$ cells). $\bullet$ IL-10 levels after stimulation with PHA (positive control), with medium alone (negative control), after stimulation with peptides AA1-50, and after stimulation with peptides AA291-330.

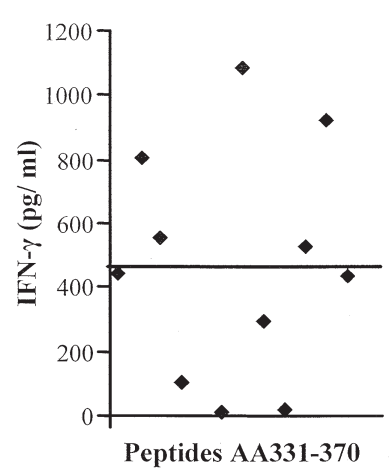

Figure 3. Expression of IFN- $\gamma$ by PBLs from patients with colorectal cancer after stimulation with wt p53 peptides in culture (amino acids AA331-370). The level of IFN- $\gamma$ secretion after stimulation with other p53 determinants was comparable to the negative control. Each spot represents one patient, the horizontal line marks the mean value of measured IFN- $\gamma$ secretion (435 pg/ml). Supernatants from ELISPOT assay were collected and measured for IFN- $\gamma$ production by ELISA

Effector cells (CD8, IFN- $\gamma$ ) and apoptotic (Fas/FasL) specific genes were also elevated in these patients at stage II (CD8,
8.6 $\pm 3.2 \Delta \mathrm{Ct}$; IFN $-\gamma, 16.3 \pm 5.3 \Delta \mathrm{Ct}$; Fas, $31.2 \pm 7.7 \Delta \mathrm{Ct}$; FasL, $18.3 \pm 5.1 \Delta \mathrm{Ct}$ ), suggesting that events important for the fate of the immunological response appear in an early stage of cancer development. The genes for T regulatory cells (CD4, CD25, CTLA4, Foxp3, GATA-3, GITR, IL-10) and for effector cells (CD8, IFN- $\gamma$, Fas/FasL) were significantly decreased in UICC stages III and IV compared to stage II $(\mathrm{p}<0.05)$.

Remarkably, in our immunohistochemical staining experiments, higher numbers of $\mathrm{CD} 4{ }^{+} \mathrm{CD} 25^{+} \mathrm{T}$ lymphocytes were detected at the tumor site of patients with UICC stage II than in patients of later disease stages (Fig. 5, CD $4{ }^{+} \mathrm{CD} 25^{+}$in UICC II vs. CD4 ${ }^{+} \mathrm{CD} 25^{+}$in UICC IV, $\left.\mathrm{p}<0.05\right)$.

\section{Discussion}

A number of observations show that $\mathrm{CD} 4^{+} \mathrm{T}$-cell responses directed to p53 are elicited during the process of tumorigenesis in vivo. First, anti-p53 antibodies displaying IgG isotypes have been detected in the blood of cancer patients (26-30). Since B-cell activation and differentiation are known to require help from activated $\mathrm{Ag}$-specific $\mathrm{CD}^{+} \mathrm{T}$ cells, it is 


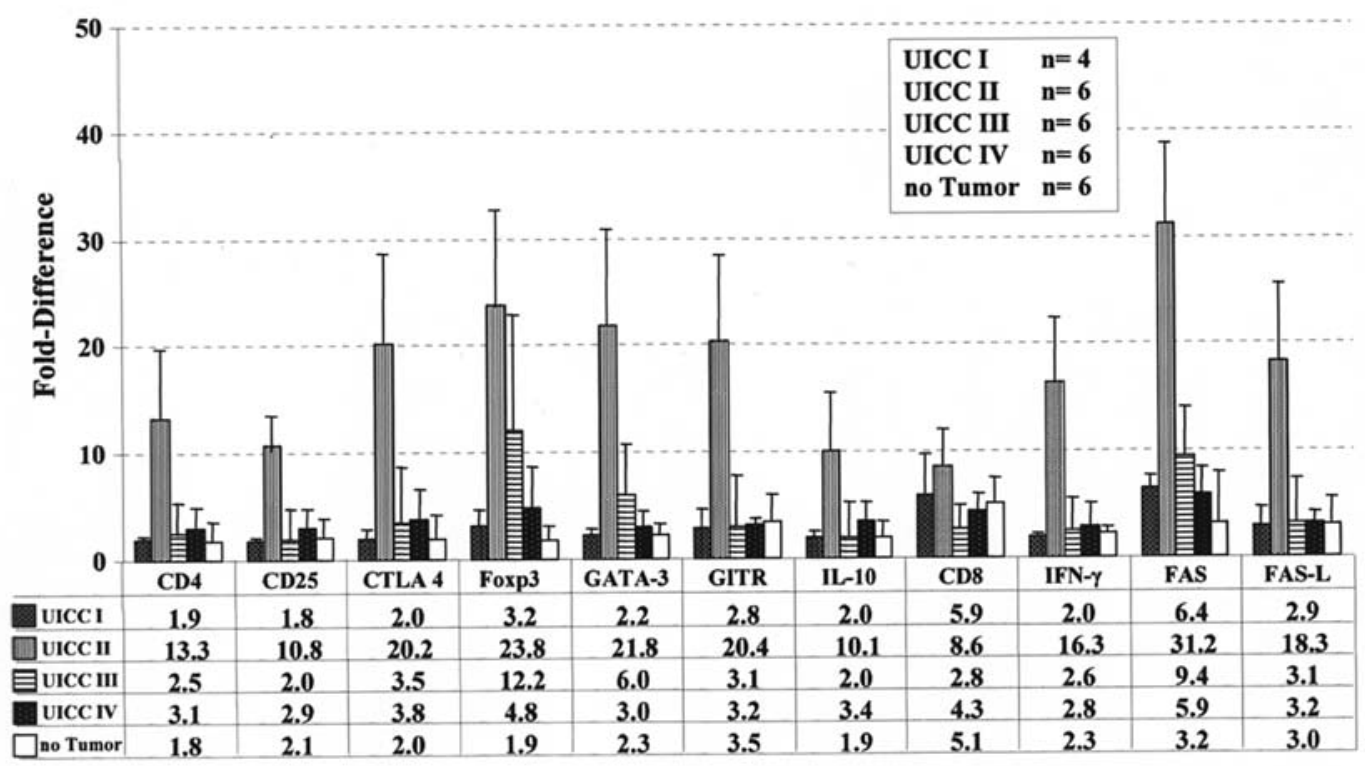

Figure 4. Expression of mRNA of IFN- $\gamma$ and IL-10, T regulatory (CD4, CD25, CTLA4, Foxp3, GATA-3, GITR) and effector cell (CD8) specific markers and apoptotic mediators (Fas, FasL) in colorectal cancer patients at different UICC stages. Increased expression of T regulatory specific genes at the tumor site in patients with UICC stage II. Effector cells (CD8, IFN- $\gamma$ ) and apoptotic (Fas/FasL) specific genes were also increased at this stage. The difference $(\Delta \mathrm{Ct})$ between the average $\mathrm{Ct}$ values of the samples in the target wells and those of the housekeeping gene, GAPDH, was assessed, followed by the difference ( $\Delta \Delta \mathrm{Ct})$ between the average $\Delta \mathrm{Ct}$ values of the samples for each target and the $\Delta \mathrm{Ct}$ value of the control sample for that target. The relative quantification value, fold change, is expressed as $2-\Delta \Delta \mathrm{Ct}$.
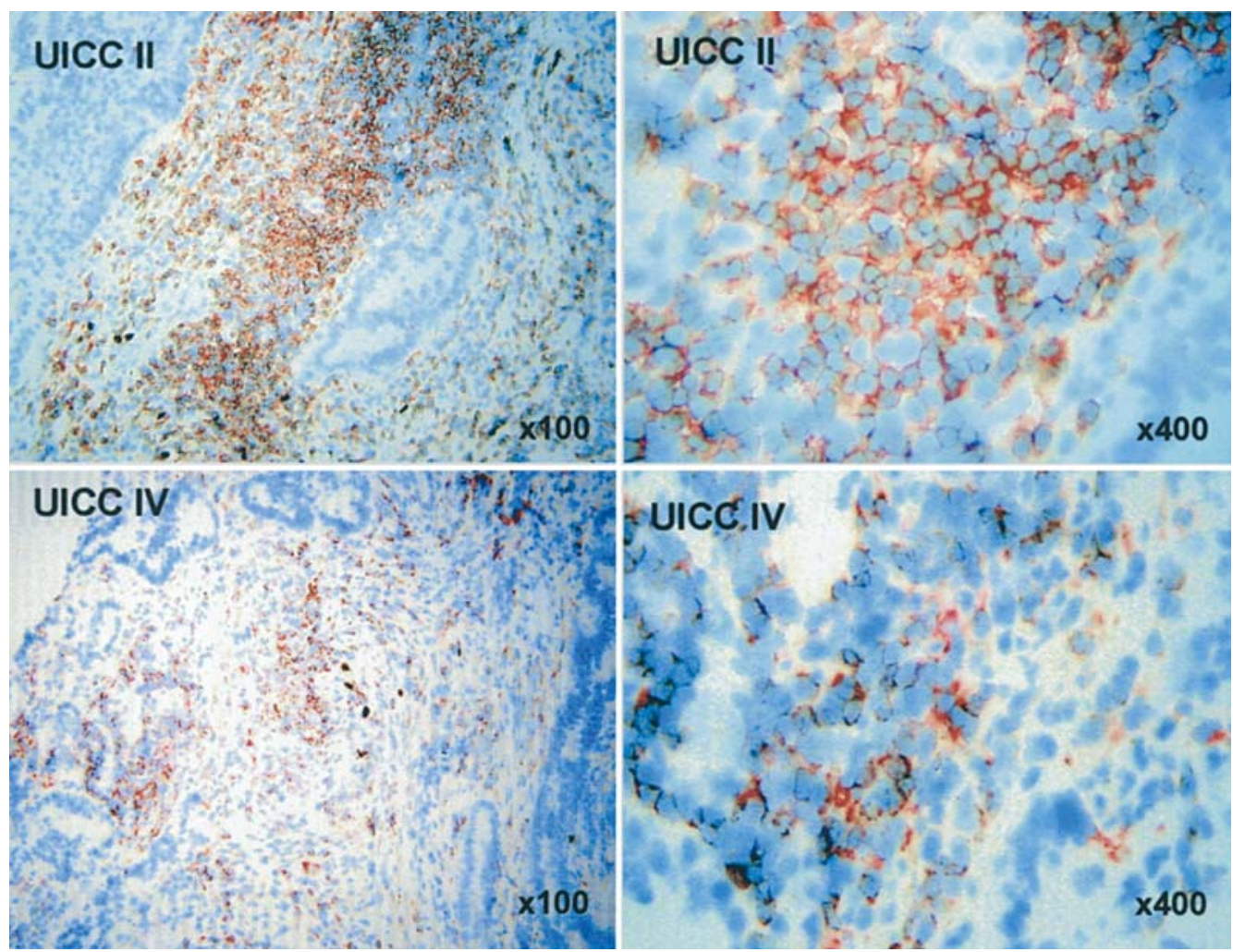

Figure 5. Representative immunohistochemical staining of infiltrating T cells from colorectal cancer patients with UICC stages II and IV. Higher numbers of $\mathrm{CD}^{+} \mathrm{CD} 25^{+} \mathrm{T}$ lymphocytes were detected in patients of UICC stage II than in patients of UICC stage IV at the tumor site. The percentage of positive cells was estimated within 20 consecutive high power fields. Original magnifications, x100 and x400.

likely that some anti-p53 CD4+ Th cells are stimulated during tumor development. Second, in patients with breast tumors expressing mut p53, PBMC have been shown to proliferate in vitro in the presence of $\mathrm{p} 53$ protein (28). While these studies suggest that anti-p53 $\mathrm{CD}^{+} \mathrm{T}$ cells become activated during cancer, the nature of the p53 determinants recognized 
by these $\mathrm{CD}^{+} \mathrm{T}$ cells as well as the functional properties of these $\mathrm{T}$ cells are still unknown. It has been demonstrated that anti-p53 T cells specific to certain wild-type p53 determinants are present in the periphery of the adult immune system and can be specifically activated after p53 peptide immunization in tumor-bearing mice (31). More importantly, mice inoculated with syngeneic $\mathbf{J} 774$ metastatic sarcomas mount a potent $\mathrm{CD}^{+} \mathrm{T}$-cell response to $\mathrm{p} 53$. This response is mediated by $\mathrm{T}$ cells recognizing the mutated portion of $\mathrm{p} 53$ and by $\mathrm{T}$ cells directed to formerly cryptic self-p53 determinants. Interestingly, the anti-p53 Th response directed toward distinct $\mathrm{p} 53$ peptides depends upon the stage of tumorigenesis (31). In the present study, we demonstrated that the presence of p53-specific IgG antibodies correlates with the strong p53 staining intensity in the tumors of patients with primary colorectal cancer, although just a minority of the examined patients $(39 \%)$ displayed a p53-specific humoral response. This correlation between intracellular accumulation of p53 in the tumor cells and the presence of humoral immunity to p53 is in accordance with previous studies (32).

Cytokine production analysis shows the UICC stagedependent wild-type p53-specific Th2 immune response in these patients, which is not necessarily associated with the presence of $\mathrm{p} 53$-specific IgG responses or specific mutations in the p53 gene. Upon stimulation of lymphocytes derived from patients with wild-type p53 peptide pools, distinct residues induced a Th2 (IL-10) or Th1 (IFN- $\gamma$ ) type response. $\mathrm{T}$ cells from the patients in UICC I/II expressed higher IL-10 levels in response to p53 peptide AA 291-330 than patients in UICC III or IV, indicating that T cells display a UICC stage-dependent IL-10 production in response to $\mathrm{p} 53$ peptides. In contrast, other p53 peptides (AA 331-370) led to IFN- $\gamma$ production but no correlation was observed between the UICC stage and the Th1 response in the ELISPOT analysis. This is consistent with our previous study in leukemic mice showing that $\mathrm{T}$ cells respond to different $\mathrm{p} 53$ peptides depending upon the stage of metastasis. Interestingly, elevated numbers of $\mathrm{CD}^{+} \mathrm{CD} 25^{+}$lymphocytes in the tumor infiltrating fraction were observed in patients with early-stage carcinoma. These results suggest that the type of tumorspecific immune response to p53 at early stages of colorectal cancer depends on the presentation and recognition of specific wild-type p53 residues. It is noteworthy that the majority of p53 determinants that are immunogenic in colorectal cancer patients induce the activation of IL-10-producing T cells. This may explain the dominance of the type $2 \mathrm{~T}$-cell response and concomitant lack of effective tumor rejection in these patients.

Both the p53-specific cellular and humoral reactivity showed no significant association with mutations within the p53 gene. These findings are in accordance with previous studies demonstrating the absence of correlation between $\mathrm{p} 53$ specific T-cell immune response in colorectal cancer patients and p53 gene mutations (33). This may suggest the presence of T-cell responses to conserved regions of p53 antigen.

Our study suggests that, through the overexpression of p53, the tumor may directly influence the outcome of immunological surveillance in patients with primary colorectal cancer in the early course of cancer development. This overexpression of p53 may lead to the induction of p53-specific Th2 cells and, subsequently, to the suppression of the Th1 type immune response by immunosuppressive cytokines such as IL-10. Multiple studies in transplantation immunology have demonstrated that Th2 type immune responses induce tolerance rather than rejection of 'foreign' tissue (34). Thus, considering a tumor a 'modified self-tissue' similar to a transplanted organ, the overexpression of p53 in the tumor could facilitate the inhibition of anti-tumor immune activity via Th2 cell stimulation $(35,36)$. This is likely to represent a mechanism by which a tumor escapes immune surveillance. This may explain why p53 overexpression is more frequently found in many malignancies with a poor prognosis $(37,38)$. The observation that the immunological response exerted by regulatory and effector $\mathrm{T}$ cells is downregulated in UICC stages III and IV indicates that the events important for the fate of the immunological response appear in the early stages of colorectal cancer development.

Two additional mechanisms related to the presentation of p53 peptides to Th2 cells could also play a role in the Th1/Th2 imbalance detected in patients with colorectal cancer. First, the failure to induce immediate effector functions mediated by CTLs could be due to insufficient amounts of p53 determinants. Our results and other studies show that colorectal tumors of early stages may be too small to release enough p53 peptides for efficient sampling by antigen presenting cells resulting in the predominance of the Th2 arm of the anti-tumor immune response (39). Second, the intestinal microenvironment which is of an anti-inflammatory rather than a pro-inflammatory nature inhibits a sufficient delivery of pro-inflammatory signals to DCs. In this case, DCs would stay in an immature state of low antigen capture activity and secretion of IL-12 (40). This would lead to a failure of polarization toward a Th1 immune response in the draining lymphoid nodes of a colorectal tumor even if sufficient amounts of p53 epitopes are presented (41). More experiments are required to verify this hypothesis. Nevertheless, our study offers a rational explanation for the failure of some clinical vaccination trials which have been undertaken with the intention to treat patients with colorectal cancer. It might be that the fate of the immunological response is already determined in early cancer stages and, therefore, these clinical trials are initiated too late in the course of tumor progression.

\section{Acknowledgements}

This work was supported by The Deutsche Bundesstiftung Umwelt (DBU, 16011). The authors thank the assistance of Mrs. Ulrike Faber and Mrs. Karla S. Stenger in the preparation of this manuscript, and Mrs. Andrea Trumpfheller, Mrs Sabine Mueller, and Mrs. Mariola Dragan for their technical support.

\section{References}

1. Hollstein M, Sidransky D, Vogelstein B and Harris CC: p53 mutations in human cancers. Science 253: 49-53, 1991.

2. Offringa R, Vierboom MP, van der Burg SH, Erdile L and Melief CJ: p53: a potential target antigen for immunotherapy of cancer. Ann NY Acad Sci 910: 223-233, 2000.

3. Mayordomo JI, Loftus DJ, Sakamoto H, et al: Therapy of murine tumors with p53 wild-type and mutant sequence peptide-based vaccines. J Exp Med 183: 1357-1365, 1996. 
4. Vierboom MP, Bos GM, Ooms M, Offringa R and Melief CJ: Cyclophosphamide enhances anti-tumor effect of wild-type p53-specific CTL. Int J Cancer 87: 253-260, 2000.

5. Van der Burg SH, De Cock K, Menon AG, et al: Long lasting p53-specific T cell memory responses in the absence of anti-p53 antibodies in patients with resected primary colorectal cancer. Eur J Immunol 31: 146-155, 2001.

6. Melief CJ, Toes RE, Medema JP, van der Burg SH, Ossendorp F and Offringa R: Strategies for immunotherapy of cancer. Adv Immunol 75: 235-282, 2000.

7. Hung K, Hayashi R, Lafond-Walker A, Lowenstein C, Pardoll D and Levitsky H: The central role of CD4(+) T cells in the antitumor immune response. J Exp Med 188: 2357-2368, 1998.

8. Fernandez NC, Lozier A, Flament C, et al: Dendritic cells directly trigger NK cell functions: cross-talk relevant in innate anti-tumor immune responses in vivo. Nat Med 5: 405-411, 1999.

9. Romani N, Ratzinger G, Pfaller K, Salvenmoser W, Stossel H, Koch F and Stoitzner P: Migration of dendritic cells into lymphatics-the Langerhans cell example: routes, regulation, and relevance. Int Rev Cytol 207: 237-270, 2001.

10. Griffith TS, Wiley SR, Kubin MZ, Sedger LM, Maliszewski CR and Fanger NA: Monocyte-mediated tumoricidal activity via the tumor necrosis factor-related cytokine, TRAIL. J Exp Med 189: 1343-1354, 1999

11. Zwaveling S, Vierboom MP, Ferreira Mota SC, et al: Antitumor efficacy of wild-type p53-specific CD4(+) T-helper cells. Cancer Res 62: 6187-6193, 2002.

12. Zwaveling S, van der Burg SH, Menon AG, Melief CJ and Offringa R: Immunotherapy of cancer through targeting of the p53 tumor antigen. Arch Immunol Ther Exp 50: 297-305, 2002.

13. Cabrera T, Angustias Fernandez M, Sierra A, et al: High frequency of altered HLA class I phenotypes in invasive breast carcinomas. Hum Immunol 50: 127-134, 1996.

14. Garrido F, Ruiz-Cabello F, Cabrera T, Perez-Villar JJ, LopezBotet M, Duggan-Keen M and Stern PL: Implications for immunosurveillance of altered HLA class I phenotypes in human tumours. Immunol Today 18: 89-95, 1997.

15. Algarra I, Collado A and Garrido F: Altered MHC class I antigens in tumors. Int J Clin Lab Res 27: 95-102, 1997.

16. De Vries TJ, Fourkour A, Wobbes T, Verkroost G, Ruiter DJ and van Muijen GN: Heterogeneous expression of immunotherapy candidate proteins gp100, MART-1, and tyrosinase in human melanoma cell lines and in human melanocytic lesions. Cancer Res 57: 3223-3229, 1997.

17. Jager E, Ringhoffer M, Karbach J, Arand M, Oesch F and Knuth A: Inverse relationship of melanocyte differentiation antigen expression in melanoma tissues and $\mathrm{CD}^{+}$cytotoxicT-cell responses: evidence for immunoselection of antigen-loss variants in vivo. Int J Cancer 66: 470-476, 1996.

18. Schwartz RH: A cell culture model for T lymphocyte clonal anergy. Science 248: 1349-1356, 1990.

19. Chen L, McGowan P, Ashe S, Johnston J, Li Y, Hellstrom I and Hellstrom KE: Tumor immunogenicity determines the effect of B7 costimulation on T cell-mediated tumor immunity. J Exp Med 179: 523-532, 1994.

20. De Smedt T, van Mechelen M, De Becker G, Urbain J, Leo O and Moser M: Effect of interleukin-10 on dendritic cell maturation and function. Eur J Immunol 27: 1229-1235, 1997.

21. Almand B, Resser JR, Lindman B, et al: Clinical significance of defective dendritic cell differentiation in cancer. Clin Cancer Res 6: 1755-1766, 2000.

22. Menon AG, Janssen-van Rhijn CM, Morreau H, et al: Immune system and prognosis in colorectal cancer: a detailed immunohistochemical analysis. Lab Invest 84: 493-501, 2004.
23. Soussi T: p53 Antibodies in the sera of patients with various types of cancer: a review. Cancer Res 60: 1777-1788, 2000.

24. Zalcman G, Tredaniel J, Schlichtholz B, et al: Prognostic significance of serum p53 antibodies in patients with limitedstage small cell lung cancer. Int J Cancer 89: 81-86, 2000.

25. Soussi T, Dehouche K and Beroud C: p53 website and analysis of p53 gene mutations in human cancer: forging a link between epidemiology and carcinogenesis. Hum Mutat 15: 105-113, 2000.

26. Winter SF, Minna JD, Johnson BE, Takahashi T, Gazdar AF and Carbone DP: Development of antibodies against p53 in lung cancer patients appears to be dependent on the type of $\mathrm{p} 53$ mutation. Cancer Res 52: 4168-4174, 1992.

27. Vennegoor CJ, Nijman HW, Drijfhout JW, et al: Autoantibodies to $\mathrm{p} 53$ in ovarian cancer patients and healthy women: a comparison between whole p53 protein and 18-mer peptides for screening purposes. Cancer Lett 116: 93-101, 1997.

28. Tilkin AF, Lubin R, Soussi T, et al: Primary proliferative $\mathrm{T}$ cell response to wild-type p53 protein in patients with breast cancer. Eur J Immunol 25: 1765-1769, 1995.

29. Carbone DP and Minna JD: In vivo gene therapy of human lung cancer using wild-type p53 delivered by retrovirus. J Natl Cancer Inst 86: 1437-1438, 1994

30. Legros $Y$, Lafon $C$ and Soussi T: Linear antigenic sites defined by the B-cell response to human p53 are localized predominantly in the amino and carboxy-termini of the protein. Oncogene 9: 2071-2076, 1994.

31. Fedoseyeva EV, Boisgerault F, Anosova NG, et al: $\mathrm{CD}^{+} \mathrm{T}$ cell responses to self- and mutated p53 determinants during tumorigenesis in mice. J Immunol 164: 5641-5651, 2000.

32. Cabelguenne A, Blons H, De Waziers I, et al: p53 alterations predict tumor response to neoadjuvant chemotherapy in head and neck squamous cell carcinoma: a prospective series. J Clin Oncol 18: 1465-1473, 2000.

33. Chen HL and Carbone DP: p53 as a target for anti-cancer immunotherapy. Mol Med Today 3: 160-167, 1997.

34. Waaga AM, Gasser M, Kist-van Holthe JE, et al: Regulatory functions of self-restricted MHC class II allopeptide-specific Th2 clones in vivo. J Clin Invest 107: 909-916, 2001.

35. Yue FY, Dummer R, Geertsen R, Hofbauer G, Laine E, Manolio S and Burg G: Interleukin-10 is a growth factor for human melanoma cells and down-regulates HLA class-I, HLA class-II and ICAM-1 molecules. Int J Cancer 71: 630-637, 1997.

36. Ludewig B, Graf D, Gelderblom HR, Becker Y, Kroczek RA and Pauli G: Spontaneous apoptosis of dendritic cells is efficiently inhibited by TRAP (CD40-ligand) and TNF-alpha, but strongly enhanced by interleukin-10. Eur J Immunol 25: 1943-1950, 1995.

37. Vogelstein B, Lane D and Levine AJ: Surfing the p53 network. Nature 408: 307-310, 2000.

38. Vousden KH and Lu X: Live or let die: the cel's response to p53. Nat Rev Cancer 2: 594-604, 2002.

39. Spiotto MT, Yu P, Rowley DA, et al: Increasing tumor antigen expression overcomes 'ignorance' to solid tumors via crosspresentation by bone marrow-derived stromal cells. Immunity 17: 737-747, 2002.

40. Messi M, Giacchetto I, Nagata K, Lanzavecchia A, Natoli G and Sallusto F: Memory and flexibility of cytokine gene expression as separable properties of human $\mathrm{T}(\mathrm{H}) 1$ and $\mathrm{T}(\mathrm{H}) 2$ lymphocytes. Nat Immunol 4: 78-86, 2003.

41. Moser B, Schaerli P and Loetscher P: CXCR5(+) T cells: follicular homing takes center stage in T-helper-cell responses. Trends Immunol 23: 250-254, 2002. 